\title{
No. III.-LAND AND FRESHWATER DECAPODA.
}

\author{
By I. A. Borradaile, M.A., Lecturer in Natural Sciences at \\ Selwoyn College, Cambridge. \\ (Communicated by J. Stanley Gardiner, M.A., F.L.S.) \\ Read 21st February, 1907.
}

The collection contains 30 species, belonging to 11 genera. None of these, however, are new to science, and all have been previously reported from some part of the Indian Ocean. There is of course nothing surprising in this fact, but it is of some importance that it should be established, especially in view of the care with which the collecting appears to have been done.

All the species in the present list were found in Minikoi or the Maldives by Mr. Gardiner's former expedition or by the Agassiz expedition, with the exception of those belonging to the genera Curadina, Palcemon, Birgus, Deckenia, Sesarma, and Varuna. On the other hand, Metasesarma rousseauxi, H. M.-Edw., found both in Minikoi and the Maldives, and Leander debilis (Dana) and L. gardineri, Borr., found in the Maldives, are not represented in the present collection. Time will probably disclose Metasesarma rousseauxi in the Seychelles, but the other cases are more doubtful. Thus the fauna of the present area is distinctly richer than that of the Maldives and Laccadives, but does not otherwise differ from it greatly.

From the geographical point of view little information can be drawn from such a collection as the present until more is known as to the means of distribution of land, and especially of freshwater, Decapoda. It is particularly unfortunate that we know so little as to the development of most of the species, whether it be direct or larval, and as to their power, at all times of life, of living in salt water.

\section{DECAPODA REPTANTIA, BRACHYURA * .}

\section{Family Potamonidæ.}

\section{Subfamily Deckeniinæ.}

Genus DECKENIA, Hlgdf., 1868.

1. Deckenia alluaudi, A. M.-Edw. \& Bouv., 1893.

A. Milne-Edwards and E. L. Bouvier, Ann. Sci. Nat. 7, xv. p. 335, pl. viii. (1893).

This very interesting species is peculiar to the Seychelles. Its only congeners are found in East Africa. It was obtained on Morne Seychellois, Mahé, 2200 feet, and Cascade River, Mahé, 800 feet.

* See 'Fauna of the Maldives and Laccadives,' ed. J. Stanley Gardiner, i. iv. pp. $424 \mathrm{ff}$. 


\title{
Family Grapsidæ.
}

Subfamily Grapsinæ.

\author{
Genus GEOGRAPSUS, Stimps., 1858.
}

2. Geograpsus crinipes (Dana), 1851.

Alcock, Journ. As. Soc. Bengal, lxix. ii. 3, p. 395 (1900)*.

Localities. Common everywhere in the Indian Ocean.

Specimens from mangrove-swamp, Silhouette I., Seychelles, and Salomon Atoll, Chagos.

\section{Geograpsus grayi (H. M.-Edw.), 1853.}

Alcock, Journ. As. Soc. Bengal, lxix. ii. 3, p. 395 (1900).

Localities. Common everywhere in the Indian Ocean. Specimens from Coetivy, and Egmont and Salomon Atolls, Chagos.

4. Geograpsus minikoiensis, Borr., 1901.

Geograpsus longitarsis, var. minikoiensis, Borradaile, Fauna \& Geog. Maldives \& Laccadives, vol. i. p. 66, fig. 12 (1901).

Locality. Coetivy, Seychelles.

Unfortunately neither of the three known specimens of this little crab is in perfect preservation. I think, however, that its specific distinctness is not doubtful.

Subfamily Varuninæ.

Genus VARUNA, H. M.-Edw., 1830.

5. Varuna littorata (Fabr.), 1798.

Alcock, Journ. As. Soc. Bengal, lxix. ii. 3, p. 401 (1900).

Locality. Praslin, Seychelles.

Subfamily Sesarminæ.

Genus SESARMA, Say, 1817.

6. Sesarma quadratum (Fabr.), 1798.

Alcock, Journ. As. Soc. Bengal, lxix. ii. 3, p. 413.

The movable finger of the only male, a young individual, has only seven ridges on the upper edge, and the dactyles of the legs are not half the length of the propodites.

Locality. Mangrove-swamp, Mahé, Seychelles.

7. Sesarma longipes, Krauss, 1843.

Alcock, Journ. As. Soc. Bengal, lxix. ii. 3, p. 424.

Alcock, who appears to have seen only female specimens, says " there are no granular

* The references in this paper will be limited to one for each species. So far as possible these will be tuken frum Alcock's work on the Indian Crabs and Coutière's monograph on the freshwater Palæmonida of Madagascar. 
or pectinated crests of any kind on the palm." This is true of the ferale, but in the niale there is a row of strong knobs on the inside of the palm, roughly parallel with the fingers, and a similar, less distinct row at right angles to this. The upper edge of the palm is marked in both sexes by a low but sharp, rough ridge. The third leg is not, in my specimens, quite two and a half times the length of the carapace.

Localities. Found in every stream in the Seychelles. Specimens from Silhouette, Praslin (700 ft.), Praslin (Anse Marie Louise), Mahé (Cascade) : all Seychelles.

8. Sesarma intermedium (de Haan).

Alcock, Journ. As. Soc. Bengal, lxix. ii. 3, p. 416.

Localiiy. Mangrove-swamp, Silhouette, Seychelles.

\title{
Family Gecarcinidæ.
}

Genus CARDISOMA, Latr., 1825.

9. Cardisoma carnifex (Hbst.), 1794.

Alcock, Journ. As. Soc. Bengal, lxix. ii. 3, p. 445.

Localities. Found throughout the Indian Ocean in marshy places. Specimens from Coetivy, Mahé, and Praslin, Seychelles, and Chagos.

10. Cardisoma hirtipes, Dana, 1851.

Alcock, Journ. As. Soc. Bengal, lxix. ii. 3, p. 447.

Locality. Farquhar Atoll.

\author{
Family Ocypodidæ. \\ Subfamily Ocypodinæ. \\ Genus $O C Y P O D E$, Fabr., 1798.
}

11. Ocypode ceratophthalma (Pallas), 1772.

Alcock, Journ. As. Soc. Bengal, lxix. ii. 3, p. 345.

Localities. Common throughout the Indian Ocean. Specimens from Seychelles, Egmont, Peros Banhos, and Ile de la Passe, Salomon Atoll, Chagos.

12. Ocypode cordimana, Desm., 1825.

Alcock, Journ. As. Soc. Bengal, lxix. ii. 3, p. 349.

Localities. Common throughout the Indian Ocean. Specimens from Praslin, Seychelles, and Salomon Atoll, Chagos. 
Genus $U C A$, Leach, 1815.

13. Uca tetragonum (Hbst.).

Alcock, Journ. As. Soc. Bengal, lxix, ii. 3, p. 357.

Localities. Common throughout the Indian Ocean. Specimens from mangrove-swamp, Mahé, Seychelles, and barachois, Diego Garcia, Chagos.

14. Uca annulipes (H. M.-Edw.), 1837.

Alcock, Journ. As. Soc. Bengal, lxix. ii. 3, p. $3 \overline{5} 3$.

Localities. Common throughout the Indian Ocean. Specimens from mangrove-swamp, Praslin, Seychelles.

\section{ANOMURA, PAGURIDEA. \\ Family Cœnobitidæ. \\ Genus BIRGUS, Leach, 1815.}

15. Birgus latro(Linn.), 1767.

Ortmann, Zool. Jahrb., Abh. f. Syst. vi. p. 319.

Localities. Common throughout the Chagos Archipelago. Specimens from Salomon, Egmont, and Peros Banhos Atolls.

Genus CENOBITA, Latr., 1826.

The following species of this genus are all common throughout the Indian Ocean.

16. Conobita perlatus, H. M.-Edw., 1837.

Ortmann, Zool. Jahrb., Abh. f. Syst. vi. p. 319.

Localities. Specimens from Salomon and Peros Banhos, Chagos.

17. Conobita rugosus, H. M.-Edw., 1837.

Ortmann, l. c. p. 317.

Localities. Specimens from Coetivy, Seychelles; St. Joseph, Amirante; Farquhar; Salomon and Peros Banhos, Chagos.

18. Conobita compressus, H. M.-Edw., 1837.

Ortmann, l. c. p. 318.

Localities. Specimens from Ile de Passe, Salomon Atoll, Chagos.

19. Conobita clypeatus, Latr., 1826.

Ortmann, l. c. p. 315.

Localities. Specimens from Silhouette I., Seychelles; Salomon and Peros Banhos, Chagos. 
NATANTIA, CARIDEA.

Family Palæmonidæ.

Genus PALAEMON, Fabr., 1798.

20. Palamon (Eupalamon) lar, Fabr., 1798.

Coutière, Ann. Sci. Nat., Zool. (8) xii. p. 292.

'The telson, in my specimen, has a short, broad, transparent point, which is outreached by the inner pair of side spines. The wrist is slightly shorter than the arm.

Localities. Cascade River, Mahé, 800 feet; Morne Seychellois River, Mahé, 1000 feet; Praslin and Silhouette Islands : all Seychelles.

21. Palamon (Eupalamon) ida, Heller, 1862.

Coutière, Ann. Sci. Nat., Zool. (8) xii. p. 303.

All the specimens are typical, save that one has only two teeth under the rostrum.

Locality. Cascade River, Mahé, Seychelles, 800 feet.

22. Palcemon (Eupalamon) ritzema, de Man, 1897.

Coutière, Ann. Sci. Nat., Zool. (8) xii. p. 314.

Locality. Stream above Côte d'Or, Praslin, Seychelles.

23. Palamon (Eupalamon) dispar, von Martens, 1868.

Coutière, Ann. Sci. Nat., Zool. (8) xii. p. 329.

Locality. Silhouette I., Seychelles.

24. P Palamon (Eupalamon) longipes, de Haan.

Ortmann, Zool. Jahrb., Abh. f. Syst. v. p. 715 (1891).

Some specimens in the collection appear to belong to this species by all their characters, but the fingers bear a few scattered hairs, and the carapace is not absolutely smooth.

Locality. Marsh on stream above Cote d'Or, Praslin, Seychelles.

\section{Family Atyidæ.}

Genus CARIDINA, H. M.-Edw., 1837.

The first four species of this genus are abundant in the streams of Mahé, Praslin, and Silhouette, all in the Seychelles.

25. Caridina typus, H. M.-Edw., 1837.

26. Caridina similis, Bouvier, 1904.

27. Caridina brevirostris, Stimps., 1860.

28. Caridina singhalensis, Ortmann, 1894.

Bouvier, Bull. Sci. Fr. Belg. 1905, p. $77 \mathrm{ff}$.

The collection contains an immense number of specimens belonging to these species, 
which are exceedingly difficult to separate, owing to their great variability in all the points which Bouvier uses to diagnose them. I think it probable that their distinctness will not eventually be upheld in all cases. Mr. Stanley Gardiner would be glad to forward the specimens to anyone who would care to examine them statistically.

29. Caridina nilotica (Roux), 1833.

Bouvier, Bull. Sci. Fr. Belg. 1905, pp. 72, 78.

The rostrum does not quite reach the end of the antennal scale in my specimens.

Locality. Cascade River, Mahé, Seychelles, $800 \mathrm{ft}$.

30. ? Caridina multidentata, Stimps., 1860.

Bouvier, Bull. Sci. Fr. Belg. 1905, p. 74.

The rostrum of my specimens is stout up to the eud, but not quite so stout as in typical specimens.

Locality. Cascade River, Mahé, Seychelles, 800 feet.

Bouvier (loc. cit.) also records C. apiocheles from the Seychelles. 